POLIIICAL ECONOMY RESEARCH INSTIIUIE

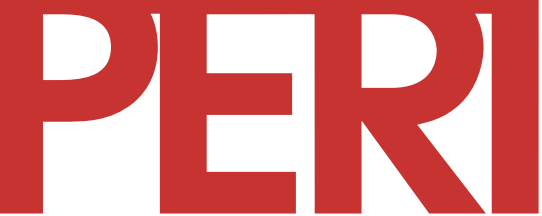

University of Massachusetts Amherst

\title{
Compensation for Environmental Services and Rural Communities: Lessons from the Americas
}

\author{
Herman Rosa, Deborah Barry, \\ Susan Kandel, and Leopoldo Dimas
}

2004

10th floor Thompson Hall University of Massachusetts Amherst, MA, 01003-7510 Telephone: (413) 545-6355 Facsimile: (413) 545-2921 Email:peri@econs.umass.edu Website:

http://www.umass.edu/peri/

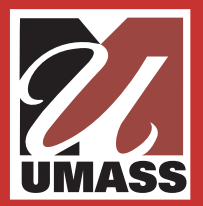




\section{Compensation for Environmental Services and Rural Communities: \\ Lessons from the Americas}

Herman Rosa, Deborah Barry, Susan Kandel, and Leopoldo Dimas

Presented at the International Conference on Natural Assets,

Tagaytay City, Philippines, January 2003

Revised July 2004 


\begin{abstract}
In principle, payments for environmental services - such as watershed management, biodiversity conservation, and carbon sequestration - can advance the goals of both environmental protection and poverty reduction. A review of recent initiatives in the Americas suggests, however, that this desirable combination is not automatic. If payments for environmental services (PES) schemes are to be an effective vehicle for strengthening livelihoods in poor rural communities, they must be designed with that objective firmly in mind. This paper draws key lessons from diverse experiences in Costa Rica, Mexico, Brazil, El Salvador, and New York.
\end{abstract}




\section{Introduction}

The degradation of the world's ecosystems is undermining their capacity to provide environmental services that are vital to humankind. This has fueled experimentation with compensation schemes that reward people for managing ecosystems to provide environmental services, based on the premise that positive incentives can lead to changes in land-use practices. In the Americas, such experiments have concentrated on watershed management for hydrological services and on conservation of biodiversity and scenic beauty. If and when international negotiations yield a suitable framework for climate change mitigation, carbon dioxide sequestration could be added to the mix.

The prevailing approach to compensation has focused on payments, rather than other possible rewards such as greater provision of local public goods or enhanced social status. In many cases, payment for environmental services (PES) schemes have been characterized by designs that seek the lowest cost possible for achieving environmental goals; concentrate on single environmental services (such as carbon sequestration), sometimes at the expense of other ecosystem services; and accord priority to simplified, large-scale ecosystems, preferably controlled by a few people, so as to reduce transaction costs.

This approach can have adverse - even devastating - impacts on poor and marginalized rural communities. At the same time, it misses opportunities for tapping into the crucial roles that these communities often play in ecosystem stewardship and the provision of environmental services. When poor communities hold secure rights over lands that provide environmental services, they are likely to benefit from compensation schemes, and the goals of environmental protection and poverty reduction are mutually supporting. More often, however, community rights to natural resources are limited and insecure. In such cases, compensation schemes can 
induce powerful outside interests to establish 'new' private property rights over resources

previously managed by poor communities, undermining their asset base and pushing them into deeper poverty.

A review of experiences with PES schemes in the Americas sheds light on both their potential as a strategy for helping poor communities to build and sustain natural assets and their limitations in contexts marked by limited and insecure property rights for the poor. This chapter summarizes lessons from an evaluation of experiences in Costa Rica, Mexico, Brazil, El Salvador, and New York, highlighting issues that need to be considered when seeking to reward poor communities for their role in ensuring the flow of environmental services. ${ }^{1}$

\section{Why Focus on Poor Communities?}

If given opportunities and technical resources to do so, the rural poor can not only reverse environmentally degrading impacts of past land-use practices but also invest in the enhancement of valuable environmental services. PES schemes are a potential strategy for bringing about these changes. From a pragmatic perspective, it often makes sense to focus these schemes on indigenous and peasant communities who inhabit, manage, and use ecosystems of importance for conservation and environmental services provision. In particular, many countries in the Americas have now adopted legal provisions that recognize and protect the rights of indigenous peoples to their land, resources, cultural identity, self-government, and participation in national affairs.

Rural communities typically have a deep relationship to the lands they occupy not only as the basis for their economic subsistence but also as a central element of their cultural identity, social organization, and belief systems. These same lands often provide important environmental services. In some cases, as in the conservation of agricultural biodiversity, these services depend 
on the labor and knowledge of community members. ${ }^{2}$ In other cases, such as regulation of the quality and quantity of water flows, human activities can have both positive and negative effects.

From an environmental justice perspective, PES schemes that fail to integrate the social objective of benefiting poor communities with the environmental objective of securing environmental services can turn into instruments of social exclusion, resulting in deeper and broader poverty. In such cases, environmental goals still may be met, but at a high social cost. In contrast, compensation strategies planned and implemented in concert with the needs of poor communities can improve both rural livelihoods and environmental management.

\section{Key Issues}

If coupled with a concern for equity and poverty reduction, compensation for environmental services can be an important tool for building natural assets in the hands of the poor. PES schemes can involve all four 'routes' for natural asset building: the redistribution and (re)appropriation of natural assets to secure the rights of low-income communities and individuals; internalization to reward them for providing benefits to others through natural resource stewardship; and further investment in natural assets induced by the resources and incentives that PES schemes provide. ${ }^{3}$

When implemented as an element of natural asset-building strategies, PES mechanisms thus can help to improve rural livelihoods while advancing environmental goals. In so doing, PES schemes can be 'consciousness-raising' in two respects. First, they can catalyze local efforts by rural communities to construct shared visions that revalorize the landscapes they manage. Second, they can raise awareness among policy makers and the public of the key roles that 
indigenous and peasant communities play in managing complex ecosystems that are critical for the provision of environmental services.

This section discusses key issues that arise in efforts to make PES schemes part of strategy for building natural assets in the hands of the poor: the need to integrate different levels of environmental services; the need for community participation to fashion equitable rules for PES schemes; the importance of a landscape perspective in resource management; the key role of social capital in efforts to build natural assets; the need for secure community rights; and the roles of the state, international donors, and non-governmental support organizations.

\section{Integrating Three Levels of Environmental Services}

Rural communities rely heavily on the natural resource base. Producers manage ecosystems with an eye toward meeting their basic needs, including food, firewood, water, and

spiritual well-being (Level 1); earning incomes by selling products (Level 2); and pursuing new alternatives linked to environmental services provision, such as water or power generation for urban areas, biodiversity conservation, and carbon sequestration (Level 3). Relationships at each level are crucial when considering PES schemes from the perspective of rural communities.

At the first level, where relations are internal to the community and not dependent on transactions with outside actors and markets, the key concerns are the rights of access to and control over natural resources. Closely connected with these are the management norms established by communities to ensure the continued flow of basic necessities. PES mechanisms can fail or prove detrimental if they fail to incorporate an understanding of how rural communities themselves value key environmental services for their own basic subsistence, identity, and spiritual well-being. 
The second level has to do with the relationship between natural resource management and income-earning strategies. In seeking better entry terms or better prices on the market, management practices can and increasingly do incorporate distinct environmental attributes or services into the production process. Where traditional production practices already incorporate 'environmentally-friendly' attributes, the main effort is one of marketing to make those attributes explicit. In other cases, practices evolve to take advantage of new opportunities. Examples that reflect both situations are organic farming, shade-grown coffee, certified sustainable forestry, ecotourism, and handicraft production. At this level, the main needs include marketing efforts, certification of practices and products, training, and specialized technical assistance.

At the third level, outside recognition is sought for the value of environmental services such as biodiversity conservation, water provision for urban centers, carbon sequestration to mitigate climate change, and other services not readily captured in a product that secures a price premium on the market. Here the challenge is finding other compensation mechanisms that recognize and reward ecosystem management practices that guarantee environmental services of interest to outside 'consumers.' This third level is without a doubt the most complex for communities, and it can be unviable or turn into a threat if not rooted in the two previous levels. Strengthening community strategies to maintain or enhance environmental services should support the integration of these levels and enable producers to overcome hurdles at each level.

\section{Rules for Applying Economic Instruments to Ensure Equity}

The concept of payment for environmental services emerged from economists' concepts of how to internalize 'positive externalities' in the production process. Mirroring the discussion on the use of economic instruments to curb negative externalities such as pollution by 
internalizing costs, PES instruments aim to maintain and expand the flow of positive externalities by internalizing benefits. Possibilities include direct payments to those responsible for maintaining certain land uses, and the development or markets for certain environmental services. Taxes and charges on consumers of environmental services can be useful for mobilizing financial resources. Payments can be targeted in exchange for specific activities that ensure the provision of environmental services.

Such economic instruments can be powerful tools for achieving environmental objectives in a cost-efficient manner. But if they are to promote equity and poverty reduction, economic instruments need to be harnessed through rules that ensure that the benefits also flow to poor rural communities. These rules relate to the requirements to participate in the PES schemes. Since these schemes involve government, donor, or other non-governmental organization (NGO) interventions, international agreements and national, state, and local governance structures, typically define the framework for applying economic instruments. In so doing, they largely determine the potential for inclusion or exclusion. When economic instruments turn out to be effective tools for strengthening the livelihoods of poor rural communities, this is usually because the governance structures ensure this outcome (IIED 2001).

In general, the rules tend to be established by more powerful and wealthy actors. Hence an explicit and deliberate effort is required to (i) ensure the participation of rural communities and the inclusion of their interests in the rule-making process; (ii) expand, defend, and secure their rights over the resource base; (iii) enhance their technical capacities and increase their market power; and (iv) strengthen their organizations.

The equity or inequity of rules is not only a matter of who receives compensation for the provision of the environmental services, but also who consumes these services and who is 
required to pay for them. If PES schemes create additional costs to consumers who are already in a highly disadvantaged position, they can result in greater inequity, including perverse arrangements where low-income communities end up paying large landowners for environmental services flowing from their lands.

Fashioning equitable rules often requires a negotiation process, which may include the determination of compensation levels. Traditional methods of economic valuation are often proposed, but these may not be particularly useful in many cases. Other techniques based on consultation and deliberation, are often more appropriate for arriving at adequate PES schemes. In Australia, for instance, the combination of multiple-criteria evaluation and a citizens' jury, informed by expert opinion, has been proposed to define values and priorities for the design of mechanisms of compensation for environmental services (Land and Water Australia 2002).

\section{Allocation: A Landscape Perspective}

A landscape can be understood as 'a geographical mosaic composed of interacting ecosystems resulting from the influence of geological, topographical, soil, climatic, biotic and human interactions in a given area'(Forest Stewardship Council 2003). A landscape perspective highlights the fact that environmental services typically are generated and distributed through a great variety of land uses, often including patchworks of forests, diverse forms of agriculture, disturbed areas, and human settlements (Gliessman 1998).

This perspective moves away from idyllic and romanticized concepts of 'undisturbed nature' to the heterogeneous complexity of land uses that exist in reality. If forces us to look at all components of the landscape, and at the particular features that impact - positively or negatively - on its capacity for generating environmental services. It also makes us look at the 
interactions amongst the components, which in some cases may be critical for generating those services. For instance, the conservation of plant species in a tropical forest can be fostered by cross-pollination with individuals in neighboring agro-forestry systems or agro-ecosystems (Gliessman 1998). Within a geographic mosaic, even disturbed patches of land can play a critical role in maintaining the flow of environmental services (see also Amanor, in this volume).

Landscape mosaics, by definition are multifunctional, providing multiple environmental services at the same time. By recognizing this complexity, a landscape perspective can avoid the dangers of focusing on a single environmental service, which, as in the case of monocultures, can promote transformations that impoverish rather than enhance the landscape as a whole. The generation and long-term conservation of environmental services require integrated management schemes that harmonize and value the diverse components of the landscape. This too often involves negotiation and conflict resolution mechanisms, given the different and at times conflicting demands, interests, and visions of the people present in a landscape mosaic.

A crucial issue when embarking upon PES schemes in rural areas is how to build the landscape-level effort and allocate the compensation. The cases studies reviewed in this chapter provide important insights and lessons on this issue. Particularly on the collective and relatively extensive landholdings of Mexico's ejidos and Brazil's extractive reserves, decisions are made regarding how to manage the delicate balance of land uses for different needs and interests, including self-consumption, collective production, harvesting for the market, raising animals, maintenance of water and fuel sources, and the location of human settlements. At the same time, decisions must be made regarding allocations among different producers and their families, taking into account their access to resources for production for self-consumption and/or 
marketable products, and the management changes and payments that are necessary for the compensation mechanism to work.

Allocation poses new questions: When and how should compensations be distributed? What changes are needed to reverse land degradation processes and ensure the future flow of environmental services, and how should individuals be compensated for possible lost income?

What are the trade-offs of introducing changes at a larger scale, above the level of the individual farm or even the ejido, for example by swapping a forested area for one under agriculture in order to improve the larger landscape? Should PES schemes stipulate or provide incentives for such changes? Could expanding the scale of management allow for changes in cropping patterns that would contribute to the provision of environmental services or increase income flows? Would collaborative efforts allow for the introduction of new activities such as eco-tourism that otherwise would not be possible? All of these questions point to the wide range of options for allocating resources and compensation. The communities themselves must help to make these choices over time.

\section{Social Capital Accumulation}

'Social capital' can be understood as the organizational capacities within a locality, and the ability of community members to secure resources (knowledge, public services, access to markets, etc.) as a result of engagement in social networks or other structures beyond the locality. Key elements are relations of confidence; reciprocity and exchanges; common rules, norms, and sanctions; and connections and networks (Pretty and Ward 2001). Thus understood, social capital is crucial for the provision of environmental services, since producers and land 
managers within a landscape mosaic need to act in a concerted fashion in order to ensure that provision.

Social capital accumulation is also essential to ensure that PES mechanisms effectively benefit poor rural communities. Without strong internal organization and external linkages, poor communities cannot influence the rules of PES schemes, nor can they effectively conduct struggles to expand, defend, and secure their rights to the resource base. Social organization is required to negotiate successfully with intermediaries and external agents, so that their proposals contribute to the diversification and strengthening of livelihoods strategies. Social organization likewise is needed to deal with internal distribution issues and other conflicts that arise when new benefits flow to a community.

Support organizations play essential roles in these processes. Institutions or NGOs that provide technical assistance, operational support, and mediation with other institutions or markets are critical to the success or failure of PES schemes. Institutions that are endogenous to the community, and outside organizations that are sensitive to local processes and that respect local decision-making, tend to favor the development of PES schemes that benefit poor rural communities.

Yet supporting institutions also can hinder appropriation by the communities. Problems can arise when intermediary organizations and communities have conflicting concepts of PES schemes. Since outside organizations usually hold the key to funds and other benefits, there is always a danger that they will try to impose their own agenda, not respecting local knowledge or the community's right to decide whether or not to enter into particular compensation mechanisms. In this regard, it is important to avoid a preconceived goal of setting up a 
compensation scheme, as it may turn out that this is not a viable or desirable option for some communities.

\section{The Precondition: Communities' Rights to Natural Resources}

The control and use of natural resources are determined to a large degree by property rights. Traditional conservation schemes seek to ensure the provision of environmental services by restricting the rights of rural communities to access and use natural resources. In effect, certain 'sticks' in the bundle of property rights are appropriated by the state. In recent years, the expansion of community rights has emerged as an alternative strategy. This reflects growing recognition that turning resource users into partners is a better way to ensure the the provision of environmental services than seeking to restrict their access. The expansion of community rights also can be an effective way to advance poverty reduction objectives, because it puts assets into the hands of the poor. In fact, defending and expanding community rights to natural resources itself can be a form of compensation in many cases, making livelihood strategies more secure and laying the groundwork for other, complementary compensation mechanisms.

The 'bundle of sticks' that constitute property rights to a natural resource often are divided among various agents. Access rights include the operational right to enter into defined areas and enjoy non-extractive benefits, such as recreation activities. Withdrawal rights give, in addition, the right to extract different products. Management rights refer to determination of patterns of resource use. Exclusion rights confer the power to decide who else can have access and extract resources. Finally, alienation rights exist when holders of these other rights can transfer them to others (Schlager and Ostrom 1992). 
Poor rural communities do not need to hold every stick in the bundle in order to internalize benefits from the flow of environmental services. But they need secure rights to at least some of the sticks. In the extractive reserves in Acre, Brazil, for example, secure access, withdrawal, and exclusion rights allow communities to be recognized and compensated for their role in maintaining the ecosystem's integrity and hence the flow of environmental services (see Hall, in this volume). Management rights, as in the case of Mexico's ejidos, go a step further by giving the communities a large say in determining land uses and production options. Land redistribution programs that convey title to the land, such as those carried out in El Salvador in the 1980s and 1990s, can expand the scope for integrating PES schemes into the livelihoods strategies of peasant communities. The expansion and defense of the property rights of poor communities can be the decisive factor both in improving the supply of environmental services and in ensuring that the poor share in the resulting stream of benefits.

\section{The State, International Donors, and Support Organizations}

The state often plays a decisive role in the orientation of PES schemes. The state can expand and defend the rights of rural communities to access, use, and control natural resources, or it can undermine these rights. A policy framework that revalues rural communities and the landscapes they manage can support community strategies to improve environmental practices. The state also generally defines the framework and rules for PES schemes. Since rules made by local power holders tend to exclude poor rural communities, state intervention is often needed to strengthen the participation of rural communities in rule-making processes.

International donor agencies can also play a critical role. To minimize the risk of compensation strategies leading to social exclusion or perverse environmental effects, donor- 
supported initiatives should build upon community perspectives and priorities, and avoid preconceived objectives. Inappropriate external 'cooperation' can actually turn into another hurdle to be overcome by communities. International donors play a positive role when they support the strengthening of social capital and negotiating platforms which enable rural communities to participate effectively in defining PES strategies, mechanisms, and ground rules.

Intermediaries at the local, national, and at times international levels are needed for activities such as research, training, certification, funds management, and market access. Yet support organizations also can have a negative influence. Large numbers of intermediaries can reduce the benefits received by producers and communities. Conflicts can arise when there are differing approaches to compensation strategies between support organizations and communities. Again, it is essential that support organizations respect communities' agendas and concerns, working collaboratively with local actors, acting transparently, and respecting community decisions regarding management of the resources under their control.

\section{Experiences in the Americas}

The outcomes of recent PES initiatives in the Americas have been shaped by their national and local contexts, and by the interests of the different stakeholders engaged in these initiatives. Costa Rica stands out as the only country in the hemisphere with an institutionalized, state-led, national system of payments for environmental services. Mexico offers important examples in a setting where peasant and indigenous communities have substantial access to and control over natural resources. In Brazil, in contrast, access to resources is more uneven and restricted, and PES initiatives have required the expansion and innovation of the rights of communities. In El Salvador, the management of agro-ecosystems and the restoration of 
degraded landscapes have been particularly important. The experience of the Watershed Agricultural Program in New York State demonstrates the importance of careful negotiations in devising PES schemes that respond to local needs. Given such diverse contexts, it would be impossible simply to copy a successful compensation scheme from one setting, and expect it to work just as well in another. Nevertheless, these experiences furnish valuable lessons that need to be taken into account in designing PES schemes that benefit rural communities.

\section{Costa Rica: Payments for Forest Services ${ }^{4}$}

Costa Rica's official PES scheme began in 1996 with amendments to the Forestry Law (Ley Forestal No. 7575), and grew out of prior experience with direct subsidies for the forestry sector. The system emphasizes global environmental services (biodiversity conservation and carbon sequestration), but it is funded primarily from a domestic tax on fossil fuels. Originally, four categories were eligible for payments on a per hectare basis: forest protection, forest management, reforestation, and tree plantations. Between 1997 and 2002, the program covered more than 300,000 hectares and total payments exceeded US\$80 million with $70 \%$ going for forest protection.

Large and medium-sized property owners were the main recipients of these payments, an outcome favored by the emphasis on conservation, the forestry orientation of the scheme, the requirement of property titles, and the use of stringent technical criteria. Over time, however, internal criticisms and pressure from indigenous and small-scale producer organizations led to more inclusive rules. The participation of indigenous reserves increased, and in 2002 agroforestry systems were made eligible for compensation. Payments for agro-forestry systems - on a basis of US\$0.60 per tree - began in 2003. 
The notion of valuing and compensating for environmental services is also present at the local level. Unlike the official PES scheme that emphasizes global services, local initiatives focus on protecting water resources for human consumption and energy generation. They also use more flexible criteria than the national system. For instance, those eligible for payments usually include those who work and live on the land, not just landowners.

Small-scale producers participating in such initiatives generally consider the local benefits (improved water and landscapes) and the technical assistance associated with the schemes, which permit production diversification and entry into new markets, to be more valuable than the payments themselves. Sometimes, however, conflicting visions with regard to natural resource use make it difficult or impossible to establish local-level PES schemes.

Seen from the perspective of poor rural communities, the Costa Rican experience, offers several lessons:

- First, it shows the importance of broad participation in the early stages of PES schemes to ensure their long-term legitimacy and sustainability. An accelerated institutionalization of PES schemes, without adequately including the interests of small producers and indigenous communities, generates restrictions that are difficult to overcome later.

- Second, without strong and representative organizations of small producers and indigenous communities, it is difficult to ensure participation that will result in truly inclusive schemes.

- Third, the global orientation, eligibility criteria, and operational rules largely determine the capacity for inclusion in the PES schemes. In some settings, greater 
inclusion requires seeing beyond the forest to link up with other productive activities that are central to livelihoods.

- Fourth, a broad focus on a wide range of practices for the provision of environmental services can be important for improving, diversifying, and strengthening the livelihood strategies of rural communities. The impact of PES schemes can be enhanced when they promote environmentally improved productive activities such as agro-forestry, agro-tourism, ecotourism, non-timber products, and sustainable agriculture.

- Finally, the incorporation of local-level perspectives, priorities, and visions can empower local communities and promote participatory management.

\section{Mexico: Community Ownership and Environmental Services ${ }^{5}$}

The most striking feature of the Mexican context is peasant and indigenous communities' access to and control over natural resources. They control half the country's land and $80 \%$ of the forests. This resource base has fostered community-based initiatives in biodiversity protection, carbon sequestration, ecotourism, and environmentally friendly production.

In the southern state of Chiapas, for example, more than 300 farmers participate in the Scolel Té project in which they plant, on average, one hectare of their individual 4-5 hectare parcels with trees to absorb carbon in exchange for direct payments. The Paris-based International Automobile Federation, the organizer of Formula One racing events, purchased the first 5,500 tons of carbon at a price of US\$10 per ton (later raised to US\$12). The payments represent modest additional income for the farmers, but more important incentives are associated 
with the possibilities to penetrate the timber market and integrate carbon sequestration into organic coffee production or other agro-ecological initiatives.

In Oaxaca, a union of indigenous communities know as UZACHI, which is engaged in sustainable community forestry, has made efforts to add environmental services to their production and management strategies. Different activities are integrated through participatory territorial planning tools that define areas for subsistence farming of corn and wheat; income generation products like timber; and the protection of biological diversity, soils, and water. UZACHI supports crop diversification through growing mushrooms, orchids, and other ornamental plants. Together with other indigenous communities and supporting NGOs, they drew up a carbon sequestration proposal for fixing 836,000 tons of carbon through silviculture and agro-silviculture systems.

Ecotourism increasingly appears as an attractive alternative for many rural communities. Various projects have shown mixed results, however, both in social and environmental terms. In Mazunte, for example, after the government issued a ban on capturing turtles, the community looked for alternative income sources and in 1992 established a 14,000-hectare Peasant Ecological Reserve and a Joint Owners Association. Seven years later, Mazunte had tourist accommodations, restaurants, businesses on the beach, and four taxis. Most of the local population lived off tourism, and there was a natural cosmetics factory and a Turtle Museum. However, this very success led to environmental stresses and the neglect of conservation. Nevertheless, ecotourism can be a promising activity when integrated into other production strategies (handicrafts, natural and organic products, etc.), especially when social organization and cohesion are strong.

Mexico's community-based initiatives provide important lessons: 
- First, when communities have broad access to the resource base, organizational capacity becomes the crucial factor for establishing agreements, complying with norms, managing conflicts, dealing with external actors, and applying territorial management strategies for environmental services provision.

- Second, it is necessary to develop participatory territorial planning and management instruments at different scales: from the plot or farm level, up to the landscape level where it may be necessary to harmonize different land uses.

- Third, peasant and indigenous communities rely heavily on the support of NGOs that assist with research, technical assistance, certification, seeking financial support, promotion, and marketing. Yet the different visions and approaches of NGOs and communication can create conflicts.

- Finally, existing production strategies provide the most convenient starting point for meeting the demand for environmental services, through diversification (as in the case of farmers who expand their agro-forestry activities for carbon sequestration or water regulation), or by means of marketing environmental services associated with their existing crops (as in the case of biodiversity-friendly shade-grown coffee). Rather than focusing on a single environmental service, communities can supply integrated services, and combine markets for environmental services with fair trade markets or solidarity markets for products of peasants and indigenous people.

\section{Brazil: Protection with People ${ }^{6}$}

Compared to Mexico, indigenous and peasant communities in Brazil have much less secure access to natural resources, which generates more precarious social conditions. For those 
reasons, the prime lessons of Brazil relate to the expansion, innovation, and defense of the rights of communities.

The traditional conservation perspective, which aims to protect natural resources by excluding people, has had a major influence in Brazil. For instance, in Vale do Ribeira, the poorest region in the state of São Paulo, more than $50 \%$ of the valley is being protected in an effort to preserve the Mata Atlántica coastal forest. To compensate municipalities for foregone revenues, the Ecological Tax on the Circulation of Markets and Services (ICMS) distributes a fraction of state sales tax revenues to municipalities in proportion to the area under conservation.

In 2001, Vale do Ribeira received 37\% of the Ecological ICMS collected in the state. Nevertheless, the municipalities in the valley consider the compensation insufficient for the livelihoods that were lost to the creation of the reserves. Barra do Turvo, a municipality that falls to a large extent within a State Park, went as so far as to ask the governor to suspend its Ecological ICMS quota payments (amounting to some US\$50,000 dollars per month), and instead allow small producers to use degraded areas of the park.

The traditional notion of protection without people is slowly giving way to more inclusive perspectives. For instance, in Jaú National Park - a World Heritage Site and Brazil's second largest national park - despite a law that formally forbids human settlements within national parks the communities living inside the park, had a say in the 1998 management plan, the first participatory plan for a Brazilian national park. Nevertheless, the legal status of the lands held by traditional communities within the park is not defined.

Extractive reserves represent a more inclusive face of conservation in Brazil. Instead of restricting access and usufruct rights of the forest communities, extractive reserves expand these rights and guarantee them by law. Formal recognition of the rights of the extractivist populations 
living within these protected areas to harvest rubber and other non-timber products is coupled with laws against forest-clearing for ranching, timber, and other operations, in effect creating new exclusion rights. In the State of Acre, for example, under the Chico Mendes Law, about US\$0.20 per kilogram of rubber collected is paid to rubber-tapper associations in recognition of their stewardship of the forest and role in guaranteeing environmental services.

Family-based agro-extractivist production is critical for the livelihoods of many communities in rural Brazil. In Gurupá, on the shores of the Amazon River, for example, community livelihoods are based on the extraction of timber, açaí, palmetto, and other nontimber products, and on subsistence agriculture. Such communities could benefit from PES schemes designed to improve the productivity, profitability, and sustainability of their activities.

The experiences in Brazil provide further lessons:

- First, a traditional conservation focus can have negative impacts on communities dependent on access to the resource base.

- Second, expanding access and usufruct rights, and compensating communities for their stewardship role can strengthen livelihoods while guaranteeing the flow of environmental services.

- Third, the use of a wide range of compensation mechanisms geared towards supporting the productive activities that preserve or enhance environmental services provision can provide the greatest benefits.

- Finally, it is crucial to integrate environmental objectives with social and equity objectives in the design and implementation of PES schemes, to ensure that they operate in favor of communities. Public discussion and decisions on rights, responsibilities, procedures, and rules can help in achieving equitable results. 
El Salvador: Environmental Services from Anthropogenic Landscapes ${ }^{7}$

El Salvador, a country of just over 20,000 square kilometers, provides an interesting set of features relevant to the design of PES schemes. These include the predominance of anthropogenic landscapes, the influence of traditional conservation discourses, strong social organizations, and a remittance-driven economy in which accelerated urbanization is accompanied by the collapse of agricultural activities in rural areas. During the 1980s and early 1990s, one-fifth of the country's territory was redistributed in a series of land reforms, broadening rural access to the resource base. The potentially beneficial effects of this greater access were undermined, however, by the profound crisis in the agricultural sector driven by falling real prices for basic grains and an unfavorable policy environment (Acevedo 1996). In this context, local initiatives are emerging that seek to identify and reinforce synergies between production, conservation, and environmental restoration in rural areas.

Given that the Salvadoran landscape is dominated almost everywhere by agro-ecosystems (notably basic grains, often on degraded hillsides; shaded-coffee on rich volcanic soils; and pasturelands), one would expect that the idea of such synergies would attract enthusiastic public support through adequate policy instruments, including PES schemes. Paradoxically, however, government initiatives supported by the Global Environmental Facility (GEF) and the World Bank appear to prioritize the use of compensation mechanisms as financial instruments for conservation alone. Insofar as the role of agro-ecosystems in the provision of global environmental services is recognized, small producers have been largely ignored. Such was the case in the GEF-World Bank funded 'Coffee and Biodiversity' project (1998-2001) that sought to conserve biodiversity on shade-grown coffee plantations. Through the certification of 
'biodiversity-friendly coffee' the project sought to enable producers to fetch price premiums on alternative coffee markets, a form of compensation for the environmental services they provide. The project worked almost exclusively with medium and large size farms, despite the fact that small farms (under 7 hectares) not only represent $80 \%$ of individual farms, but also tend to have more complex agro-ecosystems than larger farms. As mixed production systems, small farms typically provide a variety of goods besides coffee - fruit, firewood, medicinal plants, and forage - buffering households from the volatile price fluctuations of the international coffee market. This livelihood strategy also impedes large-scale clearing, which has been the response of many large holdings to the current crisis caused by very low coffee prices.

While donor projects and high-profile regional initiatives such as the Mesoamerican Biological Corridor focus on the global environmental service of biodiversity conservation, hydrological services command the greatest attention within the country. The widespread loss of capacity to regulate hydrological flows has contributed to droughts, flooding, severe water supply problems (including for the San Salvador metropolitan region), and reduced hydroelectric power generation (Barry and Rosa 1996). Accordingly, various domestic initiatives that contemplate compensation for environmental services have water as their main concern.

The Environmental Committee of Chalatenango, a poor province in the north of the country, provides an example of a regional-scale water initiative. The Committee is demanding that the San Salvador metropolitan region compensate Chalatenango communities in the upper Lempa River watershed for the provision of various water-related services, including hydroelectric energy, water supply, and clean-up of contaminants. At a micro-regional level, the Mancomunidad La Montañona, an association of seven municipalities in the province, is developing a territorial management strategy in which environmental services play a strategic 
role both in creating new economic alternatives, such as ecotourism, and providing for improved water resource management.

The experiences in El Salvador provide several lessons:

- First, seeing beyond the forests, and transcending traditional conservation perspectives, is crucial for the development of PES schemes. Improved practices in agro-ecosystems can enhance environmental services while strengthening rural livelihoods.

- Second, strong social organization is a key precondition for success. Managing heterogeneous and fragmented landscapes for environmental services requires effective collective action that can be achieved only through local negotiating processes for environmental and territorial management. Social organization is also essential for negotiating the terms of PES schemes and ensuring an equitable distribution of benefits.

- Third, favorable policy environment for rural areas is a must. Recognizing and rewarding the role of rural communities as providers of environmental services requires an institutional framework for the management of anthropogenic landscapes, and the agricultural sector that goes well beyond the scope of traditional policies in both agriculture and conservation.

- Finally, genuine participation is needed to define policies and rules. Public policies and PES schemes can and should build upon local initiatives that attempt to integrate environmental objectives into development strategies. 
Lessons from New York ${ }^{8}$

New York City's water supply system provides its 7.4 million residents - along with some 1.5 million visitors, workers, and residents of neighboring communities - with 1.4 billion gallons of water per day. The water is obtained from the Delaware, Catskill, and Croton watersheds, with the first two providing about $90 \%$ of the city's water supply.

In 1989, the United States Environmental Protection Agency (EPA) promulgated a new Surface Water Treatment Rule that required the filtration of public water obtained from surface sources, unless stringent public health criteria were met and an approved watershed management strategy was put in place. The estimated capital cost of a filtration system for the Catskill/Delaware watersheds was US\$6 billion, with another $\$ 200-\$ 300$ million per year needed for operation and maintenance costs. Faced with such daunting costs, the New York City Department of Environmental Protection instead tried in 1990 to impose new land use regulations that would have severely limited agricultural opportunities and rural livelihoods in the watershed areas. This reflected a vision of the Catskills region simply as a source of water, and of farmers as a threat. In contrast, for the farmers the watershed represented livelihoods, identity, and community. They organized to resist the new regulations.

The struggle was resolved through negotiations that lasted several years and involved numerous stakeholders. In the end, the City accepted agriculture as a preferred land use for the watershed, while the farmers accepted commitments to transform their practices, with support from the City, so as to guarantee a supply of clean water. The 1997 watershed management strategy that formalized this outcome includes several initiatives to support farmers' activities that improve the quality of the water supply. Its centerpiece is the Watershed Agricultural Program, a voluntary, locally administered program whereby City funds are used to implement 
environmentally friendly practices on watershed farms. Participating farmers receive technical assistance to develop a 'Whole Farm Plan', a comprehensive strategy for controlling potential sources of pollution on the farm. New York City authorities cover the costs associated with the implementation of new practices, which often include technical and managerial assistance, new equipment, and infrastructure improvements such as concrete floors for dairy barns.

The participating farmers are eligible for other forms of compensation, too: a Conservation Reserve Enhancement Program pays farmers to remove streamside lands from agricultural production; a Whole Farm Easement Program compensates farmers for forgoing development rights to their land; a Natural Resources Viability Program helps to develop markets for the products of watershed farmers; and a Catskill Family Farms Cooperative taps niche markets for vegetables and other produce helping farmers to achieve economies of scale and market power.

Lessons from New York City's watershed management strategy include the following:

- First, negotiation processes involving multiple stakeholders are necessary in order to harmonize opposing landscape visions and establish PES schemes adapted to the priorities of those involved.

- Second, a direct payment mechanism does not necessarily represent the most favorable or appropriate form of compensation. A package of compensations, with different components, can be more effective.

- Third, the empowerment of local actors can enhance their capabilities and generate additional incentives for the provision of environmental services.

- Finally, the state can play a key role in catalyzing processes related to compensation for environmental services. 


\section{Conclusions}

Compensation for environmental services is not a cure-all for rural poverty and environmental degradation. While not a panacea, PES schemes can be valuable for diversifying livelihood strategies; improving natural resource management; catalyzing shared visions that give new value to rural landscapes; and increasing public awareness of the key role played by indigenous and peasant communities in managing complex ecosystems that provide vital environmental services.

To realize their promise for reducing poverty, PES schemes need to be part of wider strategies that expand and defend the whole basket of assets in the hands of the poor; otherwise, they could fail to benefit the poor, or even have adverse effects on them. In the lexicon of the natural assets framework, this implies that compensation for environmental services - an internalization strategy - should be coupled with asset building strategies that extend the control of the communities over the resource base through redistribution and (re)appropriation, and that mobilize investments in restoring and improving the natural assets in the hands of the poor.

Compensation processes can best meet environmental objectives and serve the needs of rural communities, if they adopt a landscape perspective, taking into account the diverse components of the landscape and their interactions. PES schemes with a broad landscape perspective can catalyze local and territorial efforts to introduce more sustainable production and management practices, and facilitate building a shared vision that revalues rural landscapes managed by rural indigenous and peasant communities. Building social capital is crucial for crafting and implementing PES schemes that guarantee the provision of environmental services, benefit communities, and distribute benefits fairly within the communities. Under the right 
conditions, PES schemes focused on poor, rural communities can help to address both environmental and socio-economic challenges. 


\section{Bibliography}

Acevedo, Carlos (1996) 'Structural Adjustment, the Agricultural Sector, and the Peace Process.' In Economic Policy for Building Peace: The Lessons of El Salvador, edited by James K. Boyce. Boulder: Lynne Rienner.

Barry, Deborah, and Herman Rosa (1996) 'Environmental Degradation and Development Options.' In Economic Policy for Building Peace: The Lessons of El Salvador, edited by James K. Boyce. Boulder: Lynne Rienner.

Born, Harry Rubens, Adalberto Veríssimo, Yann Le Boulluec Alves, Manoel Pantoja da Costa, Clarissa Riccio de Carvalho, Gemima Cabral Born, and Sergio Talocchi (2002) Payment for Environmental Services: Brazil. Proyecto Pago por Servicios Ambientales en las Américas. San Salvador: PRISMA.

Boyce, James K. (2003) 'From Natural Resources to Natural Assets,' in James K. Boyce and Barry G. Shelley, eds., Natural Assets: Democratizing Environmental Ownership. Washington, D.C.: Island Press, pp. 7-28.

Boyce, James K. (2004) 'A Future for Small Farms? Biodiversity and Sustainable Agriculture,' in James K. Boyce et al., eds., Egalitarian Development in the Era of Globalization: Essays in Honor of Keith Griffin. Northampton, MA: Edward Elgar [forthcoming].

Brush, Stephen B. (2003) 'The Lighthouse and the Potato: Internalizing the Value of Crop Genetic Diversity,' in James K. Boyce and Barry G. Shelley, eds., Natural Assets:

Democratizing Environmental Ownership. Washington, D.C.: Island Press, pp. 187-205.

Burstein, J., G. Chapela, J. Aguilar, and E. De León (2002) Informe sobre la propuesta de pago por servicios ambientales en México. Proyecto Pago por Servicios Ambientales en las Américas. San Salvador: PRISMA.

Camacho, María Antonieta, Virginia Reyes, Miriam Miranda, and Olman Segura (2002) Gestión local y participación en torno al pago por servicios ambientales: Estudios de caso en Costa Rica. Proyecto Pago por Servicios Ambientales en las Américas. San Salvador: PRISMA.

Forest Stewardship Council (2003) Principles and Criteria of Forest Stewardship. Available on the worldwide web at http://www.fsc.org/fsc/how_fsc_works/policy_standards/princ_criteria.

Gliessman, Stephen R. (1998) Agroecology: Ecological Processes in Sustainable Agriculture. Chelsea, MI: Ann Arbor Press.

Herrador, D., L. Dimas, V. E. Méndez, and O. Díaz (2002) Editors. Pago por servicios ambientales en El Salvador. San Salvador: PRISMA.

IIED (2001) The Future is Now. Equity for a Small Planet. Volume 2. International Institute for Environment and Development. 
Isakson, Ryan (2002) Payment for Environmental Services in the Catskills: A socio-economic analysis of the agricultural strategy in New York City's watershed management plan. Proyecto Pago por Servicios Ambientales en las Américas. San Salvador: PRISMA.

Land and Water Australia (2002) 'Using Citizens' Juries for Making Decisions in Natural Resource Management.' Research Project No.ANU11.

Ley Forestal No. 7575. San José, Costa Rica.

Mann, Charles (2004) Diversity on the Farm. New York: Ford Foundation and Amherst, MA:

Political Economy Research Institute. Available at

http://www.umass.edu/peri/programs/development/Mann.pdf.

Pretty, Jules and Hugh, Ward (2001) 'Social Capital and the Environment.' World Development 29(2): 209-227.

Rosa, Herman, Susan Kandel, and Leopoldo Dimas (2003) Compensation for Environmental Services and Rural Communities: Lessons from the Americas and Key Issues for Strenghening Community Strategies. San Salvador: PRISMA.

Schlager, Edella and Elinor Ostrom (1992) 'Property-Rights Regimes and Natural Resources: A Conceptual Analysis.’ Land Economics 68: 249-262. 


\section{Endnotes}

${ }^{1}$ This chapter draws from the report 'Compensation for Environmental Services and Rural Communities: Lessons from the Americas and Key Issues for Strengthening Community Strategies' by Herman Rosa, Susan Kandel, and Leopoldo Dimas. This reports synthesizes the results of the Payment for Environmental Services in the Americas project sponsored by the Ford Foundation and coordinated by PRISMA (Programa Salvadoreño de Investigación sobre Desarrollo y Medio Ambiente). The full report and the country studies on which it is based can be downloaded at http://www.prisma.org.sv.

${ }^{2}$ For discussion of the role of small farmers in conserving agricultural biodiversity, see Brush (2003), Boyce (2004), and Mann (2004).

${ }^{3}$ On these four routes to natural asset-building, see Boyce (2003).

${ }^{4}$ This section is based on Camacho et al. (2002).

${ }^{5}$ This section is based on Burstein et al. (2002).

${ }^{6}$ This section is based on Born et al. (2002).

${ }^{7}$ This section is based on Herrador et al. (2002).

${ }^{8}$ This section is based on Isakson (2002). 